УДК 94(100) 61914

DOI: $10.21779 / 2542-0313-2021-36-3-37-44$

\title{
С.A. Маркарян
}

\section{Армянский вопрос на переговорах в Брест-Литовске (1917-1918 гг.)}

Ереванский государственный университет; Армения, 0025, г. Ереван, ул. Алека Манукяна, 1; markaryansamve@rambler.ru

В статье рассмотрен армянский вопрос на переговорах в Брест-Литовске в период 1917-1918 гг. Акцентировано внимание на первом этапе переговоров, выделены сложные аспекты. Обозначена позиция Ленина и Троцкого по вопросу о территориальных претензиях Германии и ее союзников. Проанализированы отдельные вопросы, которые стали «камнем преткновения». Освещен моральный фактор событий вокруг армянского вопроса на переговорах. Показано, что денонсированный Брестский договор по всем пунктам перестал действовать в том же 1918 г., кроме тех пунктов, которые касались Западной Армении.

По Лозаннским соглашениям 1923 г. правительство Кемаля Ататюрка получило международное признание и подтверждение великими державами Европы границ на западе и на востоке. Во всех последующих соглашениях 1921 и 1923 гг. турки ссылались в качестве юридического основания для владения этими территориями на объявленный недействительным и разорванный Брестский договор, а главную роль в уступке Турции этих территорий сыграл Л.Д. Троцкий.

Ключевые слова: делегачия, договор, Брест, Трочкий, Германия, Туриия, Армения.

\section{Введение}

На второй день Октябрьской революции, 26 октября 1917 г., советское правительство после одобрения Декрета о мире II Всероссийским съездом Советов по распоряжению главы советского правительства В.И. Ленина отправило правительствам стран «Четверного союза» и Антанты текст Декрета о мире [9, с. 14]. Кроме того, все послы стран Антанты получили этот текст в Петрограде [6, с. 56].

Спустя 4 дня отреагировало только правительство Германии - оно предложило объявить перемирие и выслать делегацию для переговоров в Брест-Литовск [7, с. 69]. Через несколько дней подобные предложения поступили от правительств АвстроВенгрии, Османской Турции и Болгарии. Державы Антанты проигнорировали советское предложение и не ответили на него вообще.

Советская делегация во главе с А.А. Иоффе (в составе: Л.Б. Каменев, М.Н. Покровский, Г.Я. Сокольников, М.П. Павлович, Л.М. Карахан) прибыла в Брест-Литовск 21 ноября (7 декабря) 1917 г. [2, с. 20]. Делегация Германии ее уже ждала, но переговоры начались только 22 ноября (8 декабря). Ее возглавлял статс-секретарь Министерства иностранных дел Германии фон Кюльман, австро-венгерскую делегацию - министр иностранных дел граф Чернин, турецкую - посол Османской Туреции в Берлине Хаккы-паша. На переговорах присутствовала болгарская делегация во главе с министром иностранных дел А. Поповым, но она вела себя скромно и инертно, как бы наблюдая за всем происходящим. 


\section{Первый этап переговоров}

На первом этапе переговоров Л.Д. Троцкий руководил советской делегацией из Петрограда, а в конце декабря он сам прибыл в Брест-Литовск [10, с. 110], захватив с собой текст секретного соглашения Сайкса-Пико от 1916 г., согласно которому державы Антанты соглашались после победы в войне передать России г. Константинополь (Стамбул) с проливами Босфор и Дарданеллы, а также Эрзурум, Трапезунд, Ван, Игдыр, Баязет и Битлис, т. е. фактически большую часть исторической (или Западной) Армении, которая до войны управлялась турецкой администрацией, а в 1916 г. была занята русской армией. Л. Троцкий планировал расположить к себе немцев и турок, раскрыв им текст соглашения Сайкса-Пико. Турецкая делегация настолько была шокирована этим текстом, что уже 23 ноября (9 декабря) его текст изучали в султанской канцелярии и выслали по радио в Бейрут одному из видных министров правительства младотурок Джемаль-паше [1; 6, с. 79].

Ллойд Джордж писал в своих воспоминаниях: «Уже через 2 дня после позорного большевистского демарша в Бресте мы услышали из Бейрута яркую, эмоциональную речь турецкого министра Джемаль-паши, заклеймившего Англию и Францию от имени турецкого государства» [2, с. 204-205]. Так, Л. Троцкий положил начало опубликованию всех секретных договоров и документов Министерства иностранных дел. Он считал, что стоит отказаться от трехвековой борьбы с Османской Турцией и навсегда отказаться от проливов и Константинополя, от Западной Армении в обмен на дружбу с Турцией. Было заметно, что у делегации Германии имеется страстное желание побыстрее заключить мир с Россией, чтобы перебросить все войска на Запад» [8, с. 89-90].

Германская делегация огласила 16 статей своих условий 14 декабря 1917 г. Однако глава советской делегации Л. Троцкий считал, что и Германия, и Австро-Венгрия находятся в глубочайшем социально-экономическом кризисе и стоят на пороге революции, а поэтому никакие условия мира нельзя считать приемлемыми. Он считал, что переговоры нужно тянуть до того момента, когда эта революция начнется [10, с. 89]. Дальнейшие события показали, что эти расчеты Л. Троцкого были ошибочными и революции произошли в них через год после переговоров. Понятно, что переговоры не могли продолжаться столь длительное время.

В этих 16 статьях речь шла о территориальных требованиях по отношению к Польше и Прибалтике и об «очищении от русских войск Восточной Анатолии» (Западной Армении), но не назывались конкретно ни области, ни города, откуда должны были уйти русские войска [5]. Это было чисто декларативное заявление турецкой делегации, которое можно было с большим основанием и оспаривать, и обсуждать. В общей сложности на этом этапе Германия и союзники требовали передать им около 150 тыс. км². Советская делегация прервала переговоры 24 декабря 1917 г. и через два дня прибыла в Петроград. Указания и инструкции наркома иностранных дел Л.Д. Троцкого были выполнены: «Никакого мира не подписывать, а переговоры прервать по первому удобному случаю и сразу выехать в Петроград» [3, с. 38].

Л. Троцкий доложил В. Ленину о требованиях Германии и ее союзников, после чего глава правительства потребовал немедленно выехать в Брест и подписать мир. Но вместо этого Троцкий объявил себя больным, никуда не поехал и стал тайно у себя на квартире принимать Л.Б. Каменева, Ф.Э. Дзержинского, Н.И. Бухарина, Г.Я. Сокольникова и других видных деятелей партии большевиков, надеясь сколотить мощную антиленинскую группировку в руководстве страны [3, с. 39]. Ф.Э. Дзержинский даже считал, что если Германия представляет такие условия мира, то нужно продолжить участие в Первой мировой войне до полного разгрома Германии и ее капитуляции. Тогда 
В.И. Ленин в период со 2 по 7 января 1918 г. по нескольку часов выступает на заседаниях правительства и требует немедленно подписать мир с Германией, даже угрожая своей отставкой. Уже 7 января принято постановление правительства, в котором указано «Л.Д. Троцкому немедленно выехать в Брест и в течение 2-х дней завершить переговоры подписанием мира».

Выполняя это постановление, Троцкий выехал в Брест, и уже 9 января 1918 г. переговоры возобновились. Они шли безрезультатно 10 дней, пока главнокомандующий германской армией фельдмаршал Гинденбург не потребовал от главы немецкой делегации фон Кюльмана немедленно предъявить ультиматум русской стороне и в случае неприятия его угрожал начать наступление немецкой армии на Петроград [8, с. 209].

\section{Прерванные переговоры в Бресте}

Германская делегация прервала переговоры и выехала в Берлин, а советская делегация во главе с Троцким осталась на этот раз в Бресте. В.И. Ленин снова потребовал по телеграфу немедленно подписать мир. Германская делегация решила усилить давление на Троцкого и 17 января подключила делегацию Османской Турции с более резким заявлением о необходимости очистить от русских войск не только Эрзурум, Трапезунд, Ван, Муш, Битлис, но и давно уже принадлежавшие России (с 1878 г.) Карс, Артвин и Ардаган [2, с. 19]. Правда, фон Кюльман умерил турецкие аппетиты и заявил, что речь может идти об очищении от русских войск только тех территорий, которые были заняты в ходе военных действий на Кавказе в 1915-1916 гг. [2, с. 20].

Вместо того чтобы поддержать эту позицию, Л.Д. Троцкий заявил турецкой и германской делегации уже на второй день после этого демарша: «...очищение от русских войск армянских земель Турции мы уже начали. Подобно тому, как мы выводили свои войска из Персии (Ирана), мы их выведем скоро и из Армении (Турецкой. C. M.)» $[10$, c. 106]. Это заявление Л. Троцкий сделал, даже не посоветовавшись с Лениным или другими членами Политбюро партии большевиков. Это заявление было сделано в то время, когда турецкая армия терпела поражение от арабов в Ираке и Иордании, покинула под давлением англичан Сирию и Палестину и готова была отступать от русских войск на Южном Кавказе в Центральную Анатолию.

\section{Консультации германской делегации по вопросу о мире}

Германская делегация в Берлине обсуждала свои дальнейшие действия, а в начале февраля фельдмаршал Гинденбург снова обратился к кайзеру Вильгельму II с требованием немедленно прекратить всякие переговоры с Россией и начать наступление на Петроград [10, с. 188]. Под давлением Гинденбурга кайзер уже 6 февраля прислал телеграмму фон Кюльману, в которой потребовал предъявить России ультиматум немедленно [10, с. 127]. Ультиматум Германии был предъявлен 9 февраля 1918 г. В ответ Л. Троцкий произнес вторично в Бресте свою формулу: «Ни мира, ни войны. Войну прекращаем, армию демобилизуем» [8, с. 89]. Он приказал прекратить переговоры и всей делегации уехать в Петроград.

Л.Д. Троцкий пишет в своих воспоминаниях, что он рассчитывал на то, что если немцы и найдут 2-3 боеспособные дивизии, им понадобится не менее 12 дней, чтобы дойти до Петрограда, а за это время советское правительство вполне могло переехать в Москву, а если понадобится - в Екатеринбург, а вот туда уже немцы не скоро доберутся [8, с. 108-109]. Трудно себе представить более авантюрную позицию. 


\section{Армянский вопрос на переговорах в Бресте}

Армянский вопрос на переговорах в Бресте после 17 января уже не сходил с повестки дня, о чем бы ни шли обсуждения и дискуссии. Шаг за шагом, поэтапно, почувствовав, что от Троцкого можно добиться больше того, о чем в начале переговоров даже не мечтала турецкая делегация, ее глава Хакки-паша, по-восточному льстя всем членам делегации советской России, постоянно жаловался им на несправедливость и грабительский характер требований царского правительства к Османской Турции, на непомерные аппетиты Николая II в отношении «восточных территорий, населенных армянами».

При этом с 17 января Хакки-паша ежедневно устраивал званые обеды и произносил тосты о борьбе с хищниками-империалистами Англии и Франции, которая непременно сближает Турцию с Россией и будет служить основой их дружбы. При этом он как бы невзначай вставлял в свою речь фразы об исторической доброжелательности русских к тюркам, огузам, татарам, башкирам, которые строили великое русское государство вместе с русским народом. Особенно доставалось английской колониальной империи, которую необходимо разрушить совместными усилиями русских и турок. Хакки-паша очень пафосно говорил о желании Османской Турции быть союзницей России и авангардом распространения революционных идей среди народов Востока. Все члены советской делегации были впечатлены этими речами и, вернувшись в Петроград, взахлеб рассказывали В.И. Ленину о настроениях турецкого руководства (особенно Иоффе). И Ленин пришел к ложному выводу о том, что среди народов Востока созрела почва для распространения идей пролетарской революции. Возможно, он не до конца поверил восторженным рассказам членов советской делегации и даже сомневался в искренности дружеских чувств младотурок по отношению к советской России, но перспектива стратегического союза с Османской Турцией против Англии и Франции привлекла его и стала основой большевистской политики на Кавказе и в Средней Азии, а также в других мусульманских регионах.

Одну из тайн Брестских переговоров не подтвердил в своих воспоминаниях Л. Троцкий. Глава австрийской делегации граф Чернин еще в 1922 г. вспоминал, что 9 января вечером в обстановке большой секретности в Брест прибыл один из трех руководителей младотурецкого триумвирата - Талаат-паша [8, с. 109]. Охрана поезда никого не подпускала близко к вагонам Талаат-паши, днем он не покидал свой поезд, а вот по ночам с 10 января происходили его тайные встречи с Троцким. Никаких документов или свидетельств иного порядка, кроме признания графа Чернина, не сохранилось. Но Троцкий уклончиво пишет в своих воспоминаниях, что уже в январе 1918 г. на переговорах в Бресте «армянский вопрос играл крупнейшую роль на переговорах с турками» $[10$, c. 88]. Впоследствии Ллойд Джордж писал, что был весьма удивлен в январе 1918 г., узнав о тайных переговорах первого визиря (премьер-министра) Талаат-паши и Л. Троцкого, которые шли втайне по ночам и даже без участия германской и австрийской делегаций [8, с. 111]. Об этом ему доложила английская разведка.

В правовом отношении позиция турок была весьма уязвима: переговоры шли по итогам Первой мировой войны и с юридической точки зрения мог рассматриваться вопрос только о тех территориях, которые были заняты русской армией в ходе военных действий 1915-1916 гг., но не о территориях Карской, Ардаганской и Артвинской областей, которые султанское правительство уступило России в 1878 г. по итогам другой войны. Но Талаат-паша сразу же поставил вопрос об уступке Турции этих областей и районов вокруг горы Арарат (Сурмалинский уезд), которые все вместе составляли 26 тыс. кв. км. Кроме того, Талаат-паша требовал передать Турции район г. Батума с пор- 
том (грузинскую Аджарию) и очистить от русских войск области Трапезунда, Эрзерума, Муша, Алашкерта, Битлиса, Вана, Хлата - всего около 105 тыс. кв. км.

Отметим еще и моральный фактор событий вокруг армянских территорий: после геноцида, устроенного в апреле 1915 г. триумвиратом младотурок во главе с Энверпашой, Талаат-пашой и Джемаль-пашой, спустя всего два года один из главных организаторов этих событий требует от России армянские территории. Более того, известно, что Германия не поддерживала эти турецкие требования и, если бы Троцкий проявил достаточно настойчивости, этот вопрос можно было вообще снять с повестки дня. Уже в феврале 1918 г., выступая перед бундестагом, генерал Людендорф прямо заявил, что Германия не нуждается в таких союзниках, как Австро-Венгрия и Турция, которые больше мешают своими требованиями переговорам в Бресте, чем способствуют им.

Уже 16 февраля генерал Гофман заявил, что состояние войны возобновляется с 19 февраля и немецкая армия переходит в наступление на Петроград. Однако недалеко от Петрограда 23 февраля немецкая армия была остановлена отрядами молодой Красной Армии. Решив не рисковать далее, германское правительство в тот же день предложило перемирие и новый текст мира. Ультиматум с немецкими требованиями через два дня курьер привез в Петроград. Уже 23 февраля Троцкий подал в отставку с поста народного комиссара по иностранным делам, и Ленин эту отставку принял. На следующий день, 24 февраля, советская делегация во главе с Г.Я. Сокольниковым и Г.В. Чичериным выехала в Брест для подписания мира.

Заседание 1 марта началось с зачитывания текста немецких требований с добавлением двух новых пунктов: а) очищение всех занятых территорий в Восточной Анатолии с добавлением городских округов Ардагана, Артвина, Карса и области г. Батума; б) размещение в Крыму немецких войск. Глава немецкой делегации фон Розенберг заявил, что эти последние два пункта можно обсудить и германская сторона не будет настаивать на их безусловном принятии. Однако глава делегации России Сокольников объявил, что ничего не собирается обсуждать, а просто передаст телеграфом все немецкие условия в Петроград. Ему возражали в вагоне советской делегации Г.В. Чичерин и Л. Карахан: они считали, что с немцами, безусловно, следует обсудить эти два пункта и, возможно, добиться их отмены [4, с. 202]. Даже генерал Гофман впоследствии вспоминал, что для немецкой делегации последний этап переговоров в Бресте происходил удивительно гладко и мирно [10, с. 200]. Почувствовав, что немцы могут уступить в вопросе об армянских территориях, уже 2 марта глава турецкой делегации Хакки-паша разразился двухчасовой речью и, путая немецкие, английские и турецкие фразы доказывал исконные права Турции на Карс, Ардаган, Артвин и Батум [10, с. 87].

Перед самым подписанием договора о мире, 3 марта, глава советской делегации Сокольников сделал заявление германским журналистам: «На Кавказе, явно нарушая сформулированные германским же правительством условия ультиматума от 23 февраля и не сообразуясь с подлинной волей народов этих областей, Германия отторгает от России в пользу Турции области Ардагана, Карса и Батума» [8, с. 219]. Мирный договор в Бресте был подписан 3 марта 1918 г., и советская делегация в тот же день покинула Брест, отказавшись от приготовленного странами Четверного союза ужина.

По условиям договора Советская Россия уступила уже более 1 млн кв. км - Прибалтику, Польшу, Украину, Белоруссию, Крым, часть Донской области, а на Южном Кавказе это были более 150 тыс. кв. км (из них 26 тыс. кв. км - области Карса, Ардагана и Сурмалинский уезд) [9, с. 14]. Однако, когда в ноябре 1918 г. страны Четверного союза капитулировали в Первой мировой войне, страны Антанты потребовали в двухмесячный срок очистить все занятые Германией и ее союзниками территории, а Брестский 
мир был объявлен недействительным (денонсированным). Германия увела свои войска и из Прибалтики, и из Украины и Белоруссии, а вот Османская Турция даже из Батума не выводила свои войска.

Тем временем надо было как-то легитимизировать турецкое присутствие на всех занятых на Южном Кавказе территориях. И в марте 1921 г. в Москве прошли переговоры между российской и турецкой делегациями. Причем турецкая делегация представляла в это время лишь никем не признанные кемалистские власти, в то время как в Стамбуле пока еще заседало законное правительство Османской Турции. Советская делегация настаивала на очищении от турецких войск г. Батума и всей Аджарии, занятых турками в апреле-мае 1918 г. по условиям Брестского мира. В то же время вопрос об освобождении от турок территорий хотя бы Артвина, Ардагана и Карса, а также Сурмалинского уезда (район горы Арарат) даже не поднимался. Турки всячески тянули и придумывали все новые поводы для обоснования своих претензий на эти территории.

\section{Договор о дружбе с Турцией}

В Москве 16 марта 1921 г. был подписан договор о дружбе с турецкой делегацией без упоминания г. Батума и его округа. Красная Армия в это время подошла к г. Батуму и окружила его, потребовав от турок немедленно покинуть город. После нескольких артиллерийских обстрелов, а также узнав, что 16 марта в Москве подписан договор о дружбе и границах без упоминания в нем г. Батума, турецкая армия оставила г. Батум и всю Аджарию 19 марта 1921 г. и отступила до с. Сарпи, где и сегодня проходит граница между Республикой Грузия и Турецкой Республикой. Нет сомнений, что если бы подобным же способом Красная Армия в марте 1921 г. подошла к Карсу, Ардагану и району горы Арарат и потребовала бы очистить их от турецких войск, то турки сделали бы это, как и в случае с г. Батумом и Аджарией, поскольку после денонсации Брестского мира в ноябре 1918 г. никаких международных юридических оснований для обладания этими территориями у Турции уже не было. Но Советское правительство России в марте 1921 г. было заинтересовано только в порте Батума, а отсутствие правовых оснований для дальнейшего удержания за собой районов областей Карса, Артвина, Ардагана и Сурмалинского уезда турками было сознательно «забыто» для «задобрения» Турции и ложной надежды на ее союзничество с революционной Россией.

\section{Заключение}

Более того, чтобы получить международно-правовое признание оставления за собой всех этих занятых территорий, в октябре 1921 г. Турция настояла на подписании договора с советской Арменией в Карсе. В этом договоре в точности повторялись положения Московского договора 1921 г. об областях Карса, Артвина, Ардагана как турецких территориях. В то же время и Московский, и Карсский договоры были подписаны с кемалистскими властями, в то время как в Стамбуле заседало султанское правительство, которое никакого участия в этих переговорах и договорах не принимало. По Лозаннским соглашениям 1923 г. правительство Кемаля Ататюрка получило международное признание великими державами Европы; договор закрепил территорию Турции в границах на западе и на востоке.

Таким образом, несправедливый и вскоре денонсированный Брестский договор по всем пунктам перестал действовать в том же 1918 г., кроме тех пунктов, которые касались Западной Армении. Во всех последующих соглашениях 1921 и 1923 гг. турки ссылались в качестве юридического основания для владения этими территориями на объ- 
явленный недействительным и разорванный Брестский договор, а главную роль в уступке Турции этих территорий сыграл Л.Д. Троцкий.

\section{Литература}

1. Гарунова Н.Н., Базна (Подмогильная) И.А. Развитие агропромышленной инфраструктуры Предкавказья в контексте процессов вовлечения региона в сферу геополитических интересов России во второй половине XIX - начале XX в. (на примере Ставропольской губернии и Терской области) // Вестник Дагестанского государственного университета. Сер. 2: Гуманитарные науки. - 2018. - Т. 33, вып. 4. - С. 19-24.

2. Документы внешней политики СССР / А.А. Громыко и др. Министерство иностранных дел СССР. - М.: Госполитиздат, 1957. - 444 с.

3. Жеймо М. Геополитические условия развития восточных границ Польши после Первой мировой войны (сообщение второе) // Проблемы межрегиональных связей. -2019 . - T. 1, № 14-1. - C. 38-41.

4. Записки Джемаль-паши 1913-1919 гг. / пер. с анг. Б.Т. Руденко; предисл. Сим. Такоева. - Тифлис: Заккрайком РКП (б), 1923. - 239 с.

5. Зотова А.В., Полторак С.Н. К 100-летию Брест-Литовского договора: зарубежные источники // Вопросы истории. - 2019. - № 1. - С. 150-161. - Режим доступа: https://dlib.eastview.com/browse/doc/52734322

6. История внешней политики СССР, 1917-1980: в 2 т. / А.Л. Адамишин, А.М. Александров, А.И. Блатов и др.; под ред. А.А. Громыко, Б.Н. Пономарева. - 4-е изд., перераб. и доп. - М.: Наука, 1981. - 757 с.

7. Медоваров М.В. Кризис Австро-Венгрии и русская консервативная мысль накануне Первой мировой войны // Вестник Нижегородского университета им. Н.И. Лобачевского. - 2015. - № 1. - С. 69-77.

8. Мирные переговоры в Брест-Литовске с 22 (9 декабря) 1917 г. по 3 марта (18 февраля) 1918 г. Т. 1: Пленарные заседания; Заседания политической комиссии / Полный текст стенограмм под ред. и с примеч. А.А. Иоффе (В. Крымского), с предисл. Л.Д. Троцкого. - М.: Нар. ком. иностр. дел, 1920. - 268 с.

9. Баш А. Атаки России на Зонгулдак в Первой мировой войне (1914-1915 гг.) // Карадениз. - 2019. - Т. 1, № 42. - С. 14-34.

10. Переговоры в Брест-Литовске. Стенографический отчет. Документы. - М., 1959. - T. 1. $-230 \mathrm{c}$.

\section{References}

1. Garunova N.N. Bazna (Podmogilnaya) I.A. Development of the agro-industrial infrastructure of the Ciscaucasia in the context of the processes of involving the region in the sphere of geopolitical interests of Russia in the second half of the XIX - early XX century (on the example of the Stavropol province and the Terek region) // Bulletin of the Dagestan State University. Series 2: Humanities. - 2018. - Vol. 33, issue 4. - Pp. 19-24.

2. Documents of foreign policy of the USSR / Ministry of Foreign Affairs of the USSR; Doctor of Economics A. A. Gromyko [and others]. - Moscow: Gospolitizdat, 1957. $444 \mathrm{p}$.

3. Zeimo M. Geopolitical conditions for the development of the eastern borders after the First World War (part II) // Problems of interregional ties. - 2019. - Vol. 1, No. 14-1. Pp. 38-41.

4. Notes of Dzhemal Pasha 1913-1919 / per. from English B. T. Rudenko; with foreword Sim. Takoyva. - Tiflis: Zakraikom RCP (b), 1923. - 239 p. 
5. Zotova A.V., Poltorak S.N. To the 100th anniversary of the Brest-Litovsk Treaty: foreign sources // Questions of history. - 2019. - No. 1. - Pp. 150-161. https://dlib.eastview.com/browse/doc/52734322

6. History of foreign policy of the USSR, 1917-1980: In 2 volumes / A.L. Adamishin, A.M. Alexandrov, A.I. Blatov and others; Ed. A.A. Gromyko, B.N. Ponomareva. - 4th ed., Rev. and add. - M.: Science. - T. 2. 1945-1980 - M.: Nauka, 1981. - 757 p.

7. Medovarov M.V. The crisis of Austria-Hungary and Russian conservative thought on the eve of the First World War // Bulletin of the Nizhny Novgorod University. N.I. Lobachevsky. - 2015. - No. 1. - Pp. 69-77.

8. Peace talks in Brest-Litovsk from 22 (9 December) 1917 to 3 March (18 February) 1918 - Moscow: Nar. com. foreign cases, 1920. - Vol. 1: Plenary sessions; Meetings of the Political Commission / Full text of the transcripts, ed. and with a note. A.A. Ioffe (V. Krymsky), with a preface. L.D. Trotsky. $-1920 .-268$ p.

9. Chief A. Russia's Attack on Zonguldak in World War (1914-1915) // Black Sea International Scientific Journal. - 2019. - Vol. 1, No. 42. - Pp. 14-34.

10. Negotiations in Brest-Litovsk. Verbatim record. Documentation. Vol. 1. - M., 1959. $-230 \mathrm{p}$

Поступила в редакциию 13 мая 2021 г.

UDC 94(100) 61914

DOI: $10.21779 / 2542-0313-2021-36-3-37-44$

\section{The Armenian Question at the Talks in Brest-Litovsk}

\section{S.A. Markarian}

Yerevan State University; Armenia, Yerevan, 0025, Alek Manukyan st., 1; markaryansamve@rambler.ru

The Armenian issue at the negotiations in Brest-Litovsk in the period 1917-1918 is considered in the article. Attention is focused on the first stage of negotiations, complex aspects are highlighted. The position of Lenin and Trotsky on the issue of the territorial claims of Germany and its allies is outlined; some issues that have become a "stumbling block" are analyzed. The moral factor of the events around the Armenian issue at the talks is highlighted. Attention was drawn to the fact that the soon denounced Brest Treaty, on all points ceased to operate in the same 1918, except for those points that concerned Western Armenia.

According to the Lausanne agreements of 1923 the government of Kemal-Ataturk received international recognition and confirmation by the great powers of Europe of the borders in the west and in the east. The denounced Brest Treaty, on all points, ceased to operate in the same 1918, except for those points that concerned Western Armenia. In all subsequent agreements of 1921 and 1923 the Turks referred to the declared invalid and torn Brest Treaty as a legal basis for the possession of these territories, and L. Trotsky played the main part in th cession of these territories to Turkey.

Keywords: delegation, agreement, Brest, Trotsky, Germany, Turkey, Armenia.

Received 13 May 2021 